Groundwater Resources Program

\title{
Water-Level and Storage Changes in the High Plains Aquifer, Predevelopment to 2011 and 2009-11
}

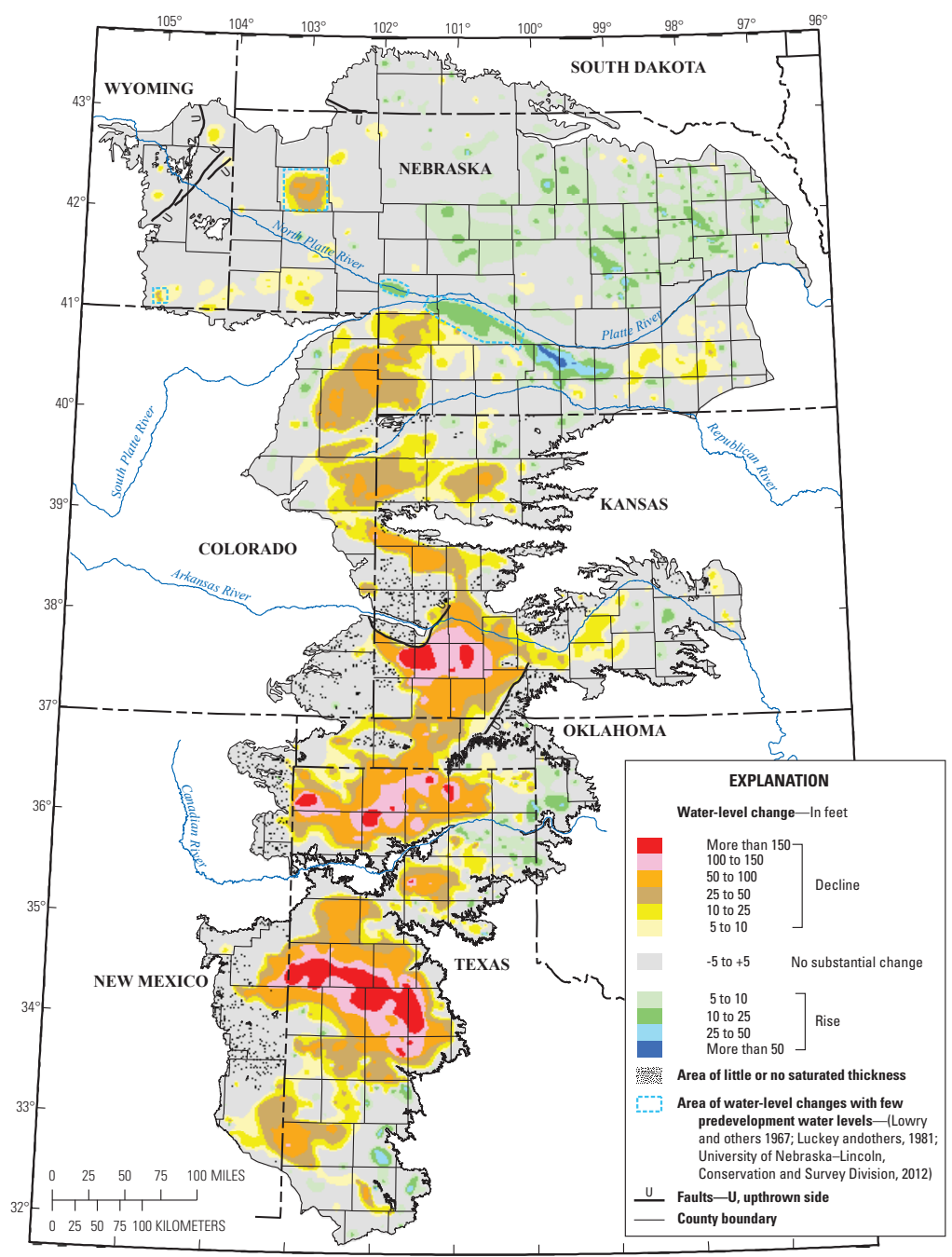

Scientific Investigations Report 2012-5291 



\section{Water-Level and Storage Changes in the High Plains Aquifer, Predevelopment to 2011 and 2009-11}

By V.L. McGuire

Groundwater Resources Program

Scientific Investigations Report 2012-5291 


\section{U.S. Department of the Interior \\ KEN SALAZAR, Secretary \\ U.S. Geological Survey \\ Marcia K. McNutt, Director}

U.S. Geological Survey, Reston, Virginia: 2013

For more information on the USGS - the Federal source for science about the Earth, its natural and living resources, natural hazards, and the environment, visit http://www.usgs.gov or call 1-888-ASK-USGS.

For an overview of USGS information products, including maps, imagery, and publications, visit http://www.usgs.gov/pubprod

To order other USGS information products, visit http://store.usgs.gov

Any use of trade, firm, or product names is for descriptive purposes only and does not imply endorsement by the U.S. Government.

Although this information product, for the most part, is in the public domain, it also may contain copyrighted materials as noted in the text. Permission to reproduce copyrighted items must be secured from the copyright owner.

Suggested citation:

McGuire, V.L., 2013, Water-level and storage changes in the High Plains aquifer, predevelopment to 2011 and 200911: U.S. Geological Survey Scientific Investigations Report 2012-5291, 15 p. (Also available at http://pubs.usgs.gov/ sir/2012/5291/.) 


\section{Contents}

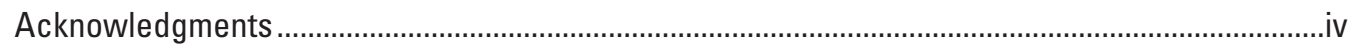

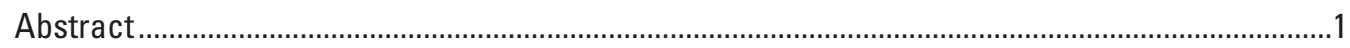

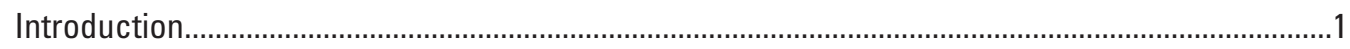

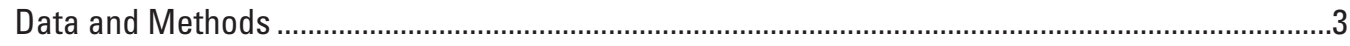

Characteristics of Raster Datasets ............................................................................................

Characteristics of Water-Level Data .....................................................................................

Characterizing Water-Level Changes, Predevelopment to 2011 .............................................4

Characterizing Water-Level Changes, 2009-11 ........................................................................

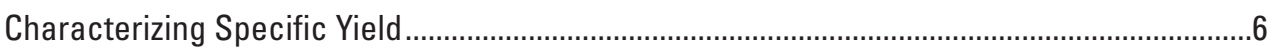

Calculation of Area-Weighted, Average Water-Level Changes, Predevelopment to 2011 ......6

Calculation of Area-Weighted, Average Water-Level Changes, 2009-11 ................................6

Calculation of Total Water in Storage and Change in Water in Storage ....................................7

Characterizing Change in Saturated Thickness, Predevelopment to 2011 ..............................7

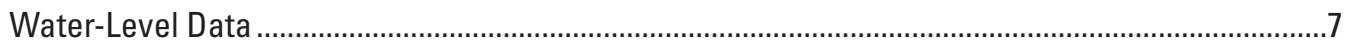

Water-Level Changes, Predevelopment to 2011 ..............................................................................

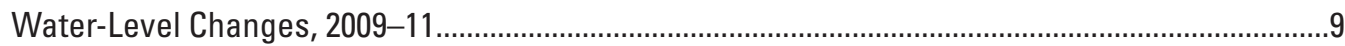

Water in Storage, Predevelopment, 1980, 2000, 2009, and 2011 .......................................................

Change in Water in Storage, Predevelopment to 2011 and 2009-11 ...............................................10

Percent Change in Saturated Thickness, Predevelopment to 2011 ..............................................11

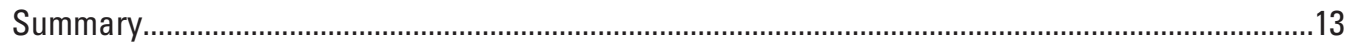

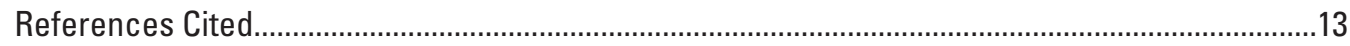

\section{Figures}

1. Map showing water-level changes in the High Plains aquifer, predevelopment

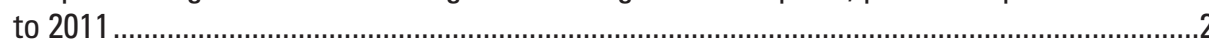

2. Map showing change in saturated thickness of the High Plains aquifer, predevelopment to 2011

\section{Tables}

1. Number of wells used in this report for 2009 and 2011 water levels, and for the water-level comparison periods, predevelopment to 2011 and 2009-11, by State and in total for the High Plains aquifer.

2. Area-weighted, average water-level changes in the High Plains aquifer, not including areas of little or no saturated thickness, predevelopment to 2011 and 2009-11, by State and as an overall total, and by comparable methods from this report and previous reports.

3. Change in water in storage in the High Plains aquifer, predevelopment to 2011 and 2009-11, by State and as an overall total, and by comparable methods from this report and previous reports. 


\section{Conversion Factors and Datum}

Inch/Pound to SI

\begin{tabular}{lcl}
\hline \multicolumn{1}{c}{ Multiply } & By & \multicolumn{1}{c}{ To obtain } \\
\hline foot $(\mathrm{ft})$ & Length & meter $(\mathrm{m})$ \\
\hline \multicolumn{1}{l}{ Area } & \\
\hline acre & 4,047 & square meter $\left(\mathrm{m}^{2}\right)$ \\
square foot $\left(\mathrm{ft}^{2}\right)$ & 0.09290 & square meter $\left(\mathrm{m}^{2}\right)$ \\
square mile $\left(\mathrm{mi}^{2}\right)^{*}$ & 2.590 & square kilometer $\left(\mathrm{km}^{2}\right)$ \\
\hline & Volume & \\
\hline gallon $($ gal $)$ & 3.785 & liter $(\mathrm{L})$ \\
gallon $($ gal) & 0.003785 & cubic meter $\left(\mathrm{m}^{3}\right)$ \\
cubic foot $\left(\mathrm{ft}^{3}\right)$ & 0.02832 & cubic meter $\left(\mathrm{m}^{3}\right)$ \\
acre-foot $(\text { acre-ft })^{* *}$ & 1,233 & cubic meter $\left(\mathrm{m}^{3}\right)$ \\
million acre-foot $(\mathrm{Macre}-\mathrm{ft})$ & $4,047,000,000$ & square meter- $\mathrm{ft}\left(\mathrm{m}^{2}-\mathrm{ft}\right)$ \\
\hline
\end{tabular}

*There are 640 acres in a square mile $\left(\mathrm{mi}^{2}\right)$.

** One acre-foot of water is equivalent to the volume of water that would cover one acre $\left(43,560 \mathrm{ft}^{2}\right)$ to a depth of 1 foot $\left(325,851\right.$ gallons or $\left.43,560 \mathrm{ft}^{3}\right)$.

Horizontal coordinate information is referenced to the North American Datum of 1983 (NAD 83).

\section{Acknowledgments}

Most of the water-level data used in this report were provided by the following local, State, and Federal entities: Colorado: Division of Water Resources (also known as the Office of the State Engineer); Kansas: Department of Agriculture-Division of Water Resources and the Kansas Geological Survey; Nebraska: Central Nebraska Public Power and Irrigation District, Natural Resources Districts, and University of Nebraska-Lincoln, Conservation and Survey Division; New Mexico: Office of the State Engineer; Oklahoma: Water Resources Board; South Dakota: Department of Environment and Natural Resources; Texas: Groundwater Conservation Districts and the Water Development Board; Wyoming: State Engineer's Office; and Federal: Bureau of Reclamation and U.S. Fish and Wildlife Service. The author thanks the above entities for providing the water-level data and for their responsiveness regarding questions about the data. 


\title{
Water-Level and Storage Changes in the High Plains Aquifer, Predevelopment to 2011 and 2009-11
}

\author{
By V.L. McGuire
}

\section{Abstract}

The High Plains aquifer underlies 111.8 million acres $(175,000$ square miles) in parts of eight States-Colorado, Kansas, Nebraska, New Mexico, Oklahoma, South Dakota, Texas, and Wyoming. Water-level declines began in parts of the High Plains aquifer soon after the beginning of substantial irrigation with groundwater in the aquifer area. This report presents water-level changes in the High Plains aquifer from the time before substantial groundwater irrigation development began (generally before 1950, and termed "predevelopment" in this report) to 2011 and from 2009-11. The report also presents total water in storage, 2011, and change in water in storage in the aquifer from predevelopment to 2011. The methods to calculate area-weighted, average water-level changes; change in water in storage; and total water in storage for this report used geospatial data layers organized as rasters with a cell size of about 62 acres. These methods were modified from methods used in previous reports in an attempt to improve estimates of water-level changes and change in water in storage.

Water-level changes from predevelopment to 2011, by well, ranged from a rise of 85 feet to a decline of 242 feet. The area-weighted, average water-level changes in the aquifer were an overall decline of 14.2 feet from predevelopment to 2011, and a decline of 0.1 foot from 2009-11. Total water in storage in the aquifer in 2011 was about 2.96 billion acrefeet, which was a decline of about 246 million acre-feet since predevelopment.

\section{Introduction}

The High Plains aquifer underlies 111.8 million acres $\left[175,000\right.$ square miles $\left.\left(\mathrm{mi}^{2}\right)\right]$ in parts of eight States-Colorado, Kansas, Nebraska, New Mexico, Oklahoma, South Dakota, Texas, and Wyoming (Qi, 2010). In the High Plains aquifer, groundwater generally occurs under unconfined conditions and the water body, from a regional perspective, has a water table at which the water pressure is atmospheric (Weeks and Gutentag, 1981). The saturated thickness of the aquifer, which is the distance from the water table to the base of the aquifer, ranges from less than 50 feet (ft) to about $1,200 \mathrm{ft}$ (McGuire and others, 2003). Gutentag and others (1984) reported that, in a few parts of the aquifer area, the water table is discontinuous; these areas total about 6.0 million acres $\left(10,780 \mathrm{mi}^{2}\right)$ and are labeled in figure 1 as "area of little or no saturated thickness." Wells drilled in areas of little or no saturated thickness (see fig. 8 in Gutentag and others, 1984) likely will not yield water unless the well penetrated saturated sediment in buried channels or depressions in the bedrock.

The area overlying the High Plains aquifer is one of the primary agricultural regions in the Nation; in parts of the area, farmers and ranchers began extensive use of groundwater for irrigation in the 1930s and 1940s. Estimated irrigated acreage in the area overlying the High Plains aquifer increased from 1940 to 1980 , but did not change greatly from 1980 to 2005: 1949-2.1 million acres, 1980-13.7 million acres, 1997-13.9 million acres, 2002-12.7 million acres, and 2005-15.5 million acres (Heimes and Luckey, 1982; Thelin and Heimes, 1987; U.S. Department of Agriculture, 1999 and 2004; Kenny and others, 2009). In 2005, irrigated acres overlaid 14 percent of the aquifer area, not including the areas with little or no saturated thickness (Kenny and others, 2009).

About every 5 years, groundwater withdrawals for irrigation and other uses are compiled from water-use data and reported by the U.S. Geological Survey (USGS) and State agencies. Groundwater withdrawals from the High Plains aquifer for irrigation increased from 4 to 19 million acre-feet (acre-ft) from 1949 to 1974; groundwater withdrawals for irrigation in 1980, 1985, 1990, and 1995 were 4 to 18 percent less than withdrawals for irrigation in 1974 (Heimes and Luckey, 1982; U.S. Geological Survey, 2008). Groundwater withdrawals from the aquifer for irrigation were 21 million acre-ft (Macre-ft) in 2000 and 19 Macre-ft in 2005 (Maupin and Barber, 2005; U.S. Geological Survey, 2008; Kenny and others, 2009).

Water-level declines began in parts of the High Plains aquifer soon after the onset of substantial irrigation using groundwater in the area-about 1950 (Gutentag and others, 1984). By 1980, water levels in the High Plains aquifer in parts of Texas, Oklahoma, and southwestern Kansas had declined more than $100 \mathrm{ft}$ (Luckey and others, 1981). 


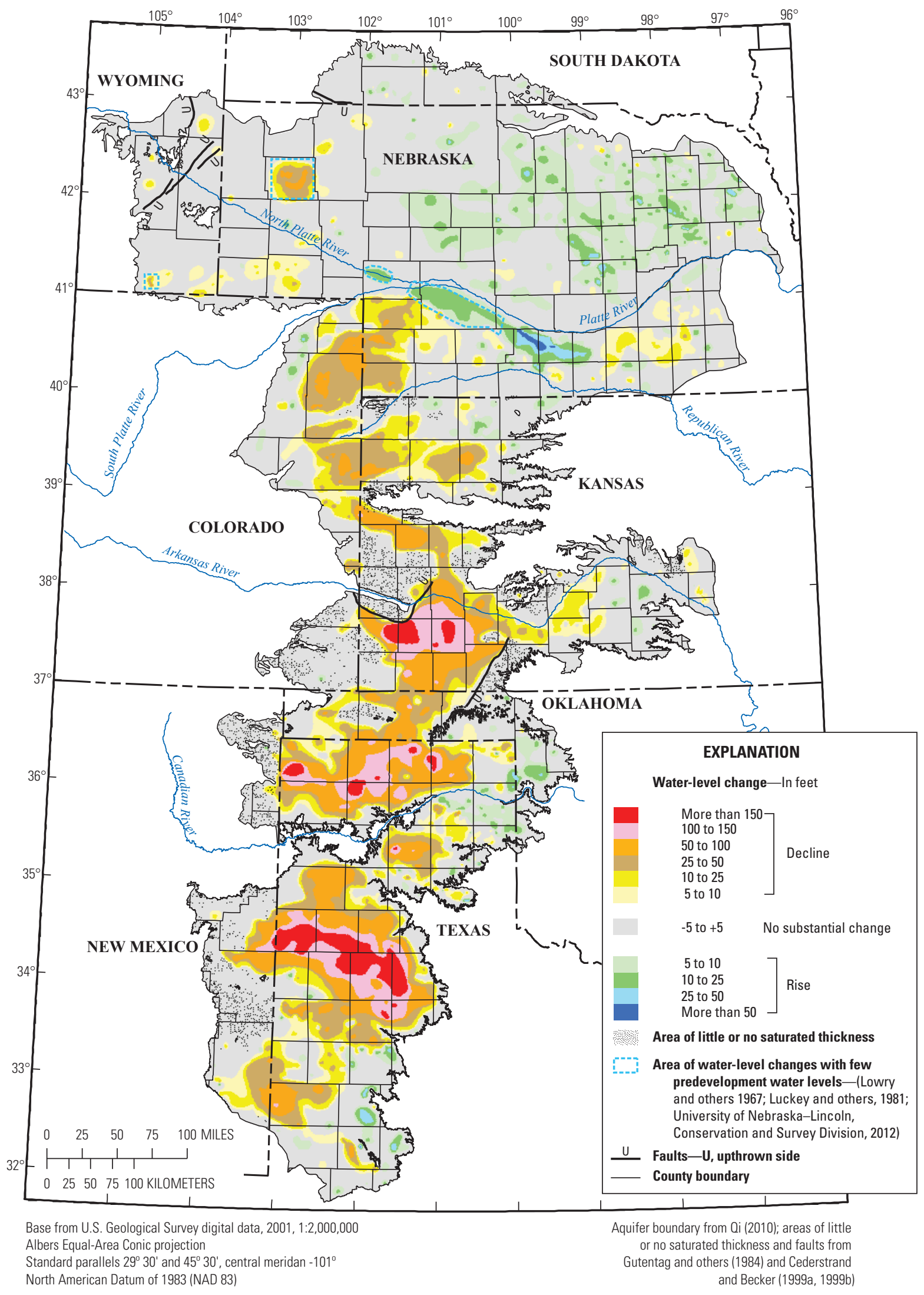

Figure 1. Water-level changes in the High Plains aquifer, predevelopment to 2011. 
Long-term water-level changes in the aquifer result from an imbalance between discharge and recharge. Discharge from the High Plains aquifer primarily consists of groundwater withdrawals for irrigation, but also includes groundwater withdrawals for public supply and other uses, evapotranspiration where the water table is near land surface, and seepage to streams, springs, and other surface-water bodies where the water table intersects the land surface (Maupin and Barber, 2005). Recharge to the aquifer primarily is from precipitation, but other sources of recharge include seepage from streams, canals, and reservoirs, and irrigation return flows (Luckey and Becker, 1999). Water-level declines may result in increased costs for groundwater withdrawals because of increased pumping lift and decreased well yields (Taylor and Alley, 2001). Water-level declines also can affect groundwater availability, surface-water flow, and near-stream (riparian) habitat areas (Alley and others, 1999).

In response to water-level declines, Congress, under the authority of Title III to the Water Resources Research Act (U.S. Public Law 98-242, 99-662), directed the USGS to monitor water levels in the aquifer; in 1987-88, the USGS, in collaboration with numerous Federal, State, and local waterresources entities, compilied water levels for 1987 and 1988 from more than 7,000 wells screened in the High Plains aquifer. Water levels for 2009 were based on measurements from 9,178 wells, and water levels for 2011 were based on measurements from 8,410 wells (table 1).

Purposes of this report are (1) to present water-level changes in the High Plains aquifer from the time before substantial development of groundwater for irrigation to 2011 and from 2009-11, and (2) to publish the raster dataset depicting water-level changes, predevelopment to 2011. The time period before substantial development of groundwater for irrigation is termed "predevelopment" in this report; predevelopment generally is before about 1950, but in some areas (for example, in the north-central part of the Texas Panhandle), predevelopment is the late 1990s, and in other areas (for example, in north-central Nebraska), groundwater has not yet (2012) been developed substantially for irrigation. Water levels used in this report generally were measured in winter or early spring, when irrigation wells typically were not pumping, and water levels generally had recovered from pumping during the previous irrigation season.

This report also describes drainable water in storage in the High Plains aquifer in 2011 and changes in both drainable water in storage and saturated thickness of the aquifer from predevelopment to 2011. Drainable water in storage is the fraction of water in the aquifer that will drain by gravity and can be withdrawn by wells. The remaining water in the aquifer is held to the aquifer material by capillary forces and generally cannot be withdrawn by wells. Drainable water in storage is termed "water in storage" in this report.

Area-weighted, average water-level changes; change in water in storage, predevelopment to 2011; and total water in storage, 2011, were calculated for this report using geospatial data organized as rasters, including available raster datasets for saturated thickness, 2009, and specific yield (Gutentag and others, 1984; Cederstrand and Becker, 1998; McGuire and others, 2012). The methods used for these calculations were modified from methods used for previous reports (McGuire, $2009,2011)$ in an attempt to improve estimates of water-level changes and change in water in storage.

\section{Data and Methods}

Table 1. Number of wells used in this report for 2009 and 2011 water levels, and for the water-level comparison periods, predevelopment to 2011 and 2009-11, by State and in total for the High Plains aquifer.

\begin{tabular}{lrrrrr}
\hline \multirow{2}{*}{ State } & \multicolumn{2}{c}{$\begin{array}{c}\text { Number of wells } \\
\text { measured }\end{array}$} & & $\begin{array}{c}\text { Number of wells used in water-level } \\
\text { comparison for indicated period }\end{array}$ \\
\cline { 2 - 3 } \cline { 6 - 6 } & $\mathbf{2 0 0 9}$ & $\mathbf{2 0 1 1}$ & & $\begin{array}{c}\text { Predevelopment } \\
\text { to } \mathbf{2 0 1 1}\end{array}$ & $\mathbf{2 0 0 9 - 1 1}$ \\
\hline Colorado & 343 & 512 & & 325 & 291 \\
Kansas & 1,745 & 1,439 & & 530 & 1,313 \\
Nebraska & 3,772 & 3,346 & & 1,504 & 3,132 \\
New Mexico & 71 & 113 & & $55^{*}$ & 33 \\
Oklahoma & 140 & 152 & & 90 & 125 \\
South Dakota & 106 & 105 & & 67 & 101 \\
Texas & 2,731 & 2,689 & & 734 & 2,330 \\
Wyoming & 270 & 54 & & 17 & 51 \\
\hline High Plains aquifer & $\mathbf{9 , 1 7 8}$ & $\mathbf{8 , 4 1 0}$ & & $\mathbf{3 , 3 2 2}$ & $\mathbf{7 , 3 7 6}$ \\
\hline
\end{tabular}

"For 24 wells in the predevelopment-to-2011 water-level comparison period, 2007, 2008, 2009 , or 2010 water levels were used instead of 2011 water levels because many wells in New Mexico were measured only once every 5 years or because the 2011 water level was not a static water level.

\section{Characteristics of Raster Datasets}

The water-volume data for this report are presented as raster datasets (hereinafter, "rasters"), which were generated using a geographic information system; the specific geographic information system used was ESRI ${ }^{\circledR}$ ArcInfo $^{\text {TM }}$ Workstation, version 10.0 (Environmental Systems Research Institute, 1992, 2010), which will hereinafter be referred as "GIS." The rasters are georeferenced to map coordinates on an Albers equal-area conic projection and using the North American Datum of 1983 (NAD 83). The cell size for all rasters was about 62 acres [ 500 meters $(\mathrm{m})$ by $500 \mathrm{~m}]$. The water-level change values were stored in units of feet. The units for change in water in storage were square meter-feet $\left(\mathrm{m}^{2}-\mathrm{ft}\right)$; and water in storage was summarized in this report in units of Macre-ft. In this report, rasters, which are presented as maps and summarized with statistics, include water-level changes, predevelopment to 2011, and percent changes in saturated thickness, predevelopment to 
2011; an additional raster for water-level changes, 2009-11, is discussed and summarized with statistics, but not shown.

\section{Characteristics of Water-Level Data}

Water-level data used in this report generally were from wells measured with an electric or steel tape using methods similar to those described by Cunningham and Schalk (2011). The wells were measured by numerous Federal, State, and local water-resources agencies, and the measurement results were loaded through the USGS Groundwater Site Inventory System (GWSI) into the USGS National Water Information System (NWIS) (U.S. Geological Survey, 2012a, 2012b).

Most of the wells were measured manually one to two times per water year. The water year starts with October of the prior year and ends with September of the given year. Generally, if a well was measured one time per water year, the well was measured in the winter or early spring; if a well was measured two times per water year, the well was measured in winter or early spring and in the late fall. Some wells were measured nearly continuously by using instrumentation (data recorders with sensors or floats) installed in the well that recorded the water level periodically (generally every 15 to 60 minutes) (Cunningham and Schalk, 2011). Water-level data used to map water-level changes were compiled for the specified water years (U.S. Geological Survey, 2012a, 2012b). Available water-level data for each well were reviewed to select a water level that (1) best represents the static water level for each applicable water year (that is, a water level that has recovered from pumping in the previous irrigation season) and (2) that is consistent with water levels in nearby wells. If a static water level was not available for a given well for the specified water year, the water-level data for that well for the specified water year were not used in this report, except as noted in table 1.

Most of the measured wells supply water for irrigation; water-level accuracy in irrigation wells can be adversely affected by excess oil used to lubricate the well's pump. The thickness of the excess oil and the depth to the oil-water interface can be measured with specialized water-level tapes; however, often these specialized tapes cannot be used in irrigation wells because opening(s) in the well casing for the measurement tape generally are not adequate. Using standard water-level tapes, the depth-to-water measurement may be underestimated as the depth to the oil floating on the water surface. Therefore, in this report, it is assumed that the accuracy of the water-level measurements ranges from 0.01 to $1 \mathrm{ft}$.

In all eight States underlain by the High Plains aquifer, available water levels for predevelopment and 1980 were compiled by Weeks and Gutentag (1981) and McGuire and others (2003). The predevelopment water level in a given well is defined as the water level in the aquifer before extensive groundwater pumping. The predevelopment water level generally was estimated by using the earliest waterlevel measurement available for more than 20,000 wells. The median measurement year in the predevelopment period was 1957 (McGuire and others, 2003). The 1980 water levels are static water levels generally measured after the irrigation season in 1979 and before the irrigation season in 1980 (that is, in water year 1980), but some were measured 1 or 2 years earlier.

In seven of the eight States that are underlain by the High Plains aquifer-Colorado, Kansas, Nebraska, Oklahoma, South Dakota, Texas, and Wyoming - most waterlevel data used in this report were from wells measured annually. In areas underlain by the High Plains aquifer in New Mexico, a substantial number of wells are measured only once every 5 or more years.

In Colorado, Kansas, Nebraska, Oklahoma, South Dakota, Texas, and Wyoming, the water levels used to map water-level changes, predevelopment to 2011, were from wells with a static water level for predevelopment and for 2011. In New Mexico, the water levels used to map waterlevel changes, predevelopment to 2011, were from wells with a static water level for predevelopment, and a static or estimated water level for 2011. A total of 24 water levels were estimated for 2011 for wells in New Mexico, which were not measured in 2011; these estimates used water levels measured in 2007 for 7 wells, in 2008 for 2 wells, in 2009 for 7 wells, and in 2010 for 8 wells.

In the eight States that are underlain by the High Plains aquifer, the water levels used to map water-level changes, 2009-11, were from wells with a measured static water level for 2009 and 2011. Estimated water levels were not used to map water-level changes, 2009-11.

\section{Characterizing Water-Level Changes, Predevelopment to 2011}

The raster of water-level changes from predevelopment to 2011 was developed by first using the GIS command "topogrid" to interpolate from point measurements to a raster of water-level changes, and then modeling the topogridoutput raster as a contoured surface using the GIS command "contour." The results of this first cut at mapping water-level changes are referred to as the initial contours. The data inputs to the GIS command "topogrid" were the water-level-change values from wells measured in the predevelopment and 2011 periods, and the contours of water-level changes, predevelopment to 2009 (McGuire, 2011). The contours of water-level changes, predevelopment to 2009, were input to the topogrid process to preserve information from discontinued waterlevel monitoring in areas with few measured wells.

The initial water-level-change contours and supplemental water-level-change data from water-level measurements in other wells and from published maps were used to create the final water-level-change contours for the 
predevelopment-to-2011 period. The supplemental waterlevel-change data were from the following sources:

1. Wells measured in the predevelopment period and, for New Mexico only, in at least one year of the 2007-10 period, but not in the 2011 period;

2. Wells measured before June 15, 1978 (but not during or before the predevelopment period for the area), and in the 2011 period;

3. Wells measured in 1980 and 2011; and

4. For parts of the aquifer in Nebraska and Wyoming with few predevelopment water levels, published maps of water-level changes since predevelopment (Lowry and others, 1967; Luckey and others, 1981; University of Nebraska-Lincoln, Conservation and Survey Division, 2012).

The initial contours of water-level changes, predevelopment to 2011, were modified manually in areas with few water-level-change values to make the interpolation more realistic. Then, polygons of water-level changes, predevelopment to 2011, were constructed using the modified contours. These polygons were converted to a raster using the GIS command "polygrid."

The GIS command "topogrid" was used again to regenerate a raster of water-level changes, predevelopment to 2011. Inputs to the second topogrid process included the same point dataset of water-level change from predevelopment to 2011, which was input to the initial "topogrid" process, and the modified contours of water-level change, predevelopment to 2011. This raster was modified further (using the GIS commands "setnull" and "con") to change the cell values to "missing data" in areas where the aquifer is not present (Gutentag and others, 1984); to change the cell values to zero in areas where water-level change ranges from a decline of less than $5 \mathrm{ft}$ to a rise of less than $5 \mathrm{ft}$; to change the cell values to "missing data" in the areas of little or no saturated thickness, as described by Gutentag and others (1984); and to examine the cell values within the polygons of water-level change to re-assign the cell, if appropriate, either (1) to the minimum value of the corresponding range for the polygon, if the cell value was less than the polygon's minimum value, or (2) to the maximum value of the corresponding range for the polygon, if the cell value was greater than the polygon's maximum value. The mapped areas between a decline of less than $5 \mathrm{ft}$ to a rise of less than $5 \mathrm{ft}$ were termed areas of no substantial change and were assigned a value of zero water-level change rather than using the GIS interpolation of water-level change values in these areas. GIS interpolation of water-level changes in these areas were not used because there was an insufficient density of wells with predevelopment and 2011 measurements for a reasonable interpolation in some of these areas. To determine the ramifications of the decision to set cells to zero in the areas of no substantial change, area-weighted, average water-level change and change in water in storage were calculated twice - once with and once without so assigning the areas between a decline of less than $5 \mathrm{ft}$ and a rise of less than $5 \mathrm{ft}$. The final raster of water-level changes, predevelopment to 2011, was used to represent cartographically waterlevel changes from predevelopment to 2011 and to calculate area-weighted, average water-level change in this report. The interpolation process used in this report results in cell values, for cells collocated with a measured well, that are generally similar to, but commonly not equal to, the corresponding values based on those water-level measurements.

The method used to characterize water-level changes since predevelopment in previous reports (McGuire, 2009, 2011) was to contour water-level changes by specified ranges and, for statistical purposes, to estimate the water-level change value at a given location in the map as the midpoint of the contour interval, which could be an over- or under-estimate of the location's value. To allow an assessment of the magnitude of method-attributable differences on the results between the method used in previous reports and the method used in this report, the method used in previous reports also was used to produce a third characterization of water-level change, predevelopment to 2011 .

\section{Characterizing Water-Level Changes, 2009-11}

The raster of water-level changes from 2009-11 was developed by first using a GIS implementation of inversedistance weighting to interpolate from point measurements of water-level change at wells measured in the 2009 and 2011 periods to an initial raster of water-level changes (using the GIS command "IDW"). Then, using the GIS command "contour," modeling the initial raster as a contoured surface to generate initial contours of water-level change ranges from a decline of less than $1 \mathrm{ft}$ to a rise of less than $1 \mathrm{ft}$.

The initial contours of water-level changes, 2009-11, which were of the area where the change ranged from a decline of less than $1 \mathrm{ft}$ to a rise of less than $1 \mathrm{ft}$, were modified manually in areas with few water-level-change values to make the interpolation more realistic. Then, polygons of water-level change, 2009-11, were constructed from these modified contours. These polygons were converted to a raster using the GIS command "polygrid."

The GIS command "topogrid" was used again to regenerate a revised raster of water-level changes, 2009-11. Inputs to the second topogrid process included the same point dataset of water-level change from 2009-11, which was input to the initial "topogrid" process, and the modified contours of waterlevel change, 2009-11. This topogrid-output raster was modified further (using the GIS commands "setnull" and "con") to change the cell values to "missing data" in areas where the aquifer is not present (Gutentag and others, 1984); to change the cell values to zero in areas where water-level change ranges from a decline of less than $1 \mathrm{ft}$ to a rise of less than $1 \mathrm{ft}$ (in recognition of estimated water-level accuracy for irrigation wells); and to change the cell values to "missing data" in the 
areas of little or no saturated thickness, as described by Gutentag and others (1984).

The method used herein for characterizing water-level change, 2009-11, was selected to generate a water-levelchange surface that would be more realistic across the aquifer area than the corresponding results from the method used in previous reports (McGuire, 2009, 2011). The interpolation process used in this report results in cell values, for cells collocated with a measured well, that are generally similar to, but commonly not equal to, the corresponding values based on those water-level measurements.

Thiessen's method (Thiessen, 1911), which was used to characterize annual water-level change in previous reports (McGuire, 2009, 2011), determines an area around each well and assigns a single value to each well's area. In Thiessen's method (Thiessen, 1911), hereinafter referred to as the "Thiessen-polygon" method, the size and shape of a well's area are determined by the proximity of neighboring wells, and water-level change measured at the well is the polygon value assigned to the well's area. In areas with widely spaced wells, the water-level change value for a given well can be assigned to a large area of the aquifer and may misrepresent water-level change for at least part of the assigned area.

\section{Characterizing Specific Yield}

Specific yield of the aquifer is used to calculate water in storage. Specific yield of a rock or soil, with respect to water, is the ratio of the volume of water, which the saturated rock or soil will yield by gravity, to the rock or soil volume (Meinzer, 1923). Specific yield was mapped for the High Plains aquifer from point estimates of area-weighted, average specific yield derived from lithologic logs for selected wells or test holes generally drilled to the base of the aquifer; the area-weighted, average specific yield of the High Plains aquifer ranges from near 0 to 30 percent. The area-weighted, average specific yield, not including the areas of little or no saturated thickness, ranges by State, from 8.1 percent in Wyoming to 18.5 percent in Oklahoma and is 15.1 percent overall for the aquifer (Gutentag and others, 1984; McGuire and others, 2012).

A specific-yield raster was created from a contour map of specific-yield ranges in the High Plains aquifer (Gutentag and others, 1984; Cederstrand and Becker, 1998). The GIS command "polygrid" was used to convert the average of the assigned range for the specific-yield polygons to a raster of the area (McGuire and others, 2012). The specific-yield value of cells in this raster of specific yield is hereafter referred to as the "average-mapped" specific-yield value.

\section{Calculation of Area-Weighted, Average Water- Level Changes, Predevelopment to 2011}

In this report, area-weighted, average water-level changes, predevelopment to 2011, were calculated directly from the final raster of water-level changes, predevelopment to 2011. This method for calculating area-weighted, average water-level changes was selected for the final calculation because the interpolated value assigned for many cells using this report's method is more realistic than the polygon-average value assigned to cells using the previous method (McGuire, 2009,2011 ), and the final raster can be used to easily calculate statistics for additional subareas of the aquifer.

Area-weighted, average water-level changes, predevelopment to 2011, were calculated a second time with the cell values in the area of water-level change from a 5 - $\mathrm{ft}$ decline to a 5 - $\mathrm{ft}$ rise unchanged from the value interpolated by GIS during the second topogrid process. The State and aquifer results from this second calculation were compared to the results obtained using this report's method to qualitatively assess the effect on the final calculations of setting the water-levelchange value to zero where the water-level-change range is between a 5 -ft decline and a 5 - $\mathrm{ft}$ rise.

Area-weighted, average water-level changes, predevelopment to 2011, were calculated a third time using the methods from previous reports (McGuire, 2009, 2011), to allow comparison of State and aquifer results using the previous method with the results obtained using this report's method. The method used in previous reports (McGuire, 2009, 2011) for calculating area-weighted, average water-level changes used the areas of the mapped polygons of intervals of waterlevel changes and the midpoint value of the interval or, for areas of declines greater than $150 \mathrm{ft}$ or rises greater than $50 \mathrm{ft}$, the beginning value of the associated polygon's water-level change interval (that is, either 150 or $50 \mathrm{ft}$, respectively).

\section{Calculation of Area-Weighted, Average Water- Level Changes, 2009-11}

In this report, area-weighted, average water-level changes, 2009-11, were calculated directly from the final raster of water-level changes, 2009-11. This method for calculating area-weighted, average water-level changes was selected for the final calculation because the value assigned for many cells is more realistic than in the previous method (McGuire, 2009, 2011), and the final raster could be used to calculate statistics for additional subareas of the aquifer.

Area-weighted, average water-level changes, 2009-11, were calculated a second time with the cell values in the area of water-level change from a $1-\mathrm{ft}$ decline to a $1-\mathrm{ft}$ rise unchanged from the value interpolated by GIS during the second topogrid process. The State and aquifer results from this calculation were compared to the results obtained using this report's method to qualitatively assess the effect on the final calculations of setting the water-level-change value to zero where the water-level-change range is between a 1 -ft decline and a 1 -ft rise.

Area-weighted, average water-level changes, 2009-11, were calculated a third time using the methods from previous reports (McGuire, 2009, 2011), to allow comparison of State and aquifer results using the previous method with the results 
obtained using this report's method. The method used in previous reports (McGuire, 2009, 2011) for calculating annual area-weighted, average water-level changes used the area and water-level change value of the Thiessen polygon.

\section{Calculation of Total Water in Storage and Change in Water in Storage}

Total water in storage, 2011, was calculated by summing the rasters of saturated thickness, 2009 (McGuire and others, 2012), and the raster of water-level changes, 2009-11, and multiplying the result by the raster of average-mapped specific yield (Gutentag and others, 1984; Cederstrand and Becker, 1998; McGuire and others, 2012) and by a conversion factor to convert $\mathrm{m}^{2} \mathrm{ft}$ to Macre-ft. Total water in storage, 2011, is not recalculated for this report using alternative methods, however, results for other years from previous reports are presented.

Changes in water in storage in the High Plains aquifer for the predevelopment to 2011 and 2009-11 time periods were calculated in this report by applying "map algebra" techniques (Tomlin and Berry, 1979) to coregistered rasters sharing a common cell size and mesh orientation. The raster of waterlevel changes for each period was multiplied by the raster of average-mapped specific yield, which ranges from 2.5 to 27.5 percent (Gutentag and others, 1984; Cederstrand and Becker, 1998; McGuire and others, 2012) and by a conversion factor to convert $\mathrm{m}^{2}-\mathrm{ft}$ to Macre-ft. Changes in water in storage from predevelopment to 2011 and from 2009-11, by State and as an overall High Plains aquifer total, were calculated by aggregating the applicable resultant raster.

Changes in water in storage, predevelopment to 2011 and 2009-11, were recalculated a second time using areaweighted, average specific yield for the aquifer (15.1 percent). The State and aquifer results from these calculations were compared to the results obtain using this report's methods to qualitatively assess the difference(s) in results by State and for the aquifer.

Change in water in storage, predevelopment to 2011 and 2009-11, were recalculated a third time using the method from previous reports (McGuire, 2009, 2011). In a previous report (McGuire, 2011), change in water in storage in the High Plains aquifer since predevelopment was calculated using the area-weighted, average specific yield of the High Plains aquifer (15.1 percent) (Gutentag and others, 1984); change in saturated volume of the High Plains aquifer, predevelopment to 2000; and change in the saturated volume of the High Plains aquifer from the corresponding annual water-level-change maps from 2000 to 2009 (McGuire, 2003, 2004a, 2004b, 2007, $2009,2011)$. The State and aquifer results from these calculations were compared to the results obtained using this report's methods to qualitatively assess the difference(s) in results by State and for the aquifer.

\section{Characterizing Change in Saturated Thickness, Predevelopment to 2011}

Change in saturated thickness, predevelopment to 2011, was mapped by contouring the ratio of water-level change, predevelopment to 2011, to predevelopment saturated thickness, using locations where this ratio was calculated for wells measured in the predevelopment and 2011 period. Predevelopment saturated thickness was calculated for each well by subtracting water-level changes, predevelopment to 2011, from calculated saturated thickness, 2011. A raster of saturated thickness, 2011, was generated by adding the raster of waterlevel change, 2009-11, to the raster of saturated thickness, 2009 (McGuire and others, 2012). The contours of change in saturated thickness were constructed initially by using the GIS command "topogrid," and then modeling the output grid as a contoured surface using the GIS command "contour." The initial change-in-saturated-thickness contours were reviewed and manually modified using supplemental data to construct the final contours. The supplemental data for changes in saturated thickness, in percent, were from the following sources:

1. Wells measured in the predevelopment period and in at least 1 year of the 2006-10 period, but not in the 2011 period;

2. Wells measured before June 15, 1978 (but not in the predevelopment period for the area), and in the 2011 period;

3. Wells measured in 1980 and in the 2011 period; and

4. For parts of the aquifer in Nebraska and Wyoming with few predevelopment water levels, published maps of water-level changes since predevelopment (Lowry and others, 1967; Luckey and others, 1981; University of Nebraska-Lincoln, Conservation and Survey Division, 2012).

\section{Water-Level Data}

Water-level data used in this report were provided by the following Federal, State, and local entities through data files or downloads from Web sites (noted below), and loaded into the USGS NWIS (U.S. Geological Survey, 2012b) through the USGS GWSI for each State overlying the High Plains aquifer (U.S. Geological Survey, 2012a):

- Colorado: Division of Water Resources (also known as the Office of the State Engineer);

- Kansas: Department of Agriculture-Division of Water Resources and the Kansas Geological Survey (Kansas Geological Survey, 2012);

- Nebraska: Central Nebraska Public Power and Irrigation District, applicable Natural Resources Districts, 
and the University of Nebraska-Lincoln, Conservation and Survey Division;

- New Mexico: Office of the State Engineer;

- Oklahoma: Water Resources Board;

- South Dakota: Department of Environment and Natural Resources;

- Texas: Groundwater Conservation Districts and the Water Development Board (Texas Water Development Board, 2012);

- Wyoming: State Engineer's Office; and

- Federal: Bureau of Reclamation, U.S. Fish and Wildlife Service, and USGS offices in Colorado, Kansas, Nebraska, New Mexico, Oklahoma, South Dakota, Texas, and Wyoming.

The data used in this report were retrieved from the USGS GWSI System for each applicable State and from USGS NWIS (U.S. Geological Survey, 2012a, 2012b).

\section{Water-Level Changes, Predevelopment to 2011}

The map of water-level changes in the High Plains aquifer from predevelopment to 2011 (fig. 1) is based on water levels from 3,322 wells (table 1) and on other published data
(Lowry and others, 1967; Luckey and others, 1981; University of Nebraska-Lincoln, Conservation and Survey Division, 2012). The other published data were used in areas in Nebraska and Wyoming with few predevelopment water levels (fig. 1). Water-level changes in wells from predevelopment to 2011 ranged from a rise of $85 \mathrm{ft}$ in Nebraska to a decline of $242 \mathrm{ft}$ in Texas; 99 percent of the wells had water-level changes from predevelopment to 2011 that ranged from a rise of $46 \mathrm{ft}$ to a decline of $186 \mathrm{ft}$. The area-weighted, average water-level change from predevelopment to 2011 was a decline of $14.2 \mathrm{ft}$. When summarized by State, the areaweighted, average water-level change from predevelopment to 2011 ranged from a decline of $39 \mathrm{ft}$ in Texas to a rise of $0.3 \mathrm{ft}$ in South Dakota (table 2).

From predevelopment to 2011, not including the areas of little or no saturated thickness, water levels declined $5 \mathrm{ft}$ or more in 33 percent of the aquifer area, $10 \mathrm{ft}$ or more in 26 percent of the aquifer area, $25 \mathrm{ft}$ or more in 19 percent of the aquifer area, and $50 \mathrm{ft}$ or more in 11 percent of the aquifer area. In approximately 54 percent of the aquifer area, waterlevel changes ranged from a 5 -ft decline to a 5 -ft rise. From predevelopment to 2011, water levels rose $5 \mathrm{ft}$ or more in 12 percent of the aquifer area and $10 \mathrm{ft}$ or more in 3 percent of the aquifer area.

The decision to set to zero the raster cells in areas where water-level change ranged from a 5 - $\mathrm{ft}$ decline to a 5 - $\mathrm{ft}$ rise was examined by recalculating area-weighted, average water-level change from predevelopment to 2011 without altering the cell values from their topogrid-interpolated value. The resulting area-weighted, average water-level change for the aquifer

Table 2. Area-weighted, average water-level changes in the High Plains aquifer, not including areas of little or no saturated thickness, predevelopment to 2011 and 2009-11, by State and as an overall total, and by comparable methods from this report and previous reports.

[Positive values for water-level rises; negative values for water-level declines; "no substantial change" defined as changes between a 5-foot decline and a 5-foot rise for predevelopment to 2011 and changes between a 1-foot decline and a 1-foot rise for 2009-11]

\begin{tabular}{|c|c|c|c|c|c|c|}
\hline \multirow{3}{*}{ State } & \multicolumn{6}{|c|}{ Area-weighted, average water-level change, in feet } \\
\hline & \multicolumn{2}{|c|}{$\begin{array}{l}\text { Final values calculated for this } \\
\text { report, with areas of no substantial } \\
\text { change set to zero feet }\end{array}$} & \multicolumn{2}{|c|}{$\begin{array}{l}\text { Calculated in this report, with areas } \\
\text { of no substantial change interpo- } \\
\text { lated using the available data }\end{array}$} & \multicolumn{2}{|c|}{$\begin{array}{l}\text { Calculated using methods } \\
\text { from previous reports }\end{array}$} \\
\hline & $\begin{array}{c}\text { Predevelopment } \\
\text { to } 2011\end{array}$ & 2009-11 & $\begin{array}{c}\text { Predevelopment } \\
\text { to } 2011\end{array}$ & 2009-11 & $\begin{array}{c}\text { Predevelopment } \\
\text { to } 2011\end{array}$ & 2009-11 \\
\hline Colorado & -12.9 & 0.3 & -12.9 & 0.2 & -13.4 & 0.6 \\
\hline Kansas & -23.6 & -1.1 & -23.5 & -1.1 & -23.5 & -1.3 \\
\hline Nebraska & 0.2 & 0.8 & 0.7 & 0.9 & -0.6 & 1.4 \\
\hline New Mexico & -14.9 & -0.3 & -15.2 & -0.3 & -15.1 & -0.7 \\
\hline Oklahoma & -11.1 & -0.6 & -11.0 & -0.8 & -12.1 & -1.2 \\
\hline South Dakota & 0.3 & 0.2 & 1.9 & 0.2 & 0.1 & 0.4 \\
\hline Texas & -39.0 & -1.2 & -38.9 & -1.2 & -38.1 & -1.7 \\
\hline Wyoming & -0.9 & 0.2 & -1.1 & 0.3 & -0.4 & 1.1 \\
\hline High Plains aquifer & -14.2 & -0.1 & -13.9 & -0.2 & -14.4 & 0.0 \\
\hline
\end{tabular}

'McGuire, 2009, 2011 
overall was a decline of $13.9 \mathrm{ft}$, and area-weighted, average water-level changes by State ranged from a decline of about $39 \mathrm{ft}$ in Texas to a rise of $1.9 \mathrm{ft}$ in South Dakota. These results indicate that the decision to substitute a water-level change of zero for those ranging from a $5-\mathrm{ft}$ decline to a $5-\mathrm{ft}$ rise did not substantially affect the area-weighted, average water-levelchange calculations for the aquifer or for most of the States (table 2). The exceptions were the results for South Dakota and Nebraska, where substitution of zero for small changes resulted in area-weighted, average water-level-change values that were $0.5 \mathrm{ft}$ lower for Nebraska, and $1.6 \mathrm{ft}$ lower for South Dakota, than the corresponding values obtained with no substitutions. These differences in Nebraska and South Dakota imply that topogrid-interpolated water-level changes were generally greater than zero, rather than an average of near zero, in the areas between declines less than $5 \mathrm{ft}$ and greater than $5 \mathrm{ft}$. However, since a large part of these areas in Nebraska and South Dakota are without water-level measurements, there is uncertainty about the accuracy of these interpolations in these States. In this report, the selected approach for final values of water-level change was, for areas with changes ranging from a 5 -ft decline to a 5 - $\mathrm{ft}$ rise, to substitute zero change, because of the inherent uncertainty in measuring water levels in irrigation wells (as much as $\pm 1 \mathrm{ft}$ ) and, especially for the predevelopment period, an insufficient data density to accurately characterize small water-level changes in parts of the area to which substitutions were applied.

Using the method from previous reports (McGuire, 2009, 2011), area-weighted, average water-level change in the High Plains aquifer from predevelopment to 2011 was a $14.4-\mathrm{ft}$ decline. Area-weighted, average water-level changes by State ranged from a decline of about $38 \mathrm{ft}$ in Texas to a rise of $0.1 \mathrm{ft}$ in South Dakota (table 2). These results using the method from a previous report (McGuire, 2011) do not vary substantially from the results obtained using this report's method.

\section{Water-Level Changes, 2009-11}

Water levels were measured in 7,376 wells before the irrigation season in 2009 and 2011 (table 1). Water-level changes in the measured wells ranged from about a $26-\mathrm{ft}$ decline in Texas to about a 16-ft rise in Colorado; 99 percent of the wells had water-level changes from 2009-11 that ranged from a decline of $13 \mathrm{ft}$ to a rise of $10 \mathrm{ft}$. Water levels declined $3 \mathrm{ft}$ or more in 11 percent of the measured wells; water levels declined $6 \mathrm{ft}$ or more in 4 percent of the measured wells. The area-weighted, average water-level changes from 2009-11 by State ranged from a $1.2-\mathrm{ft}$ decline in Texas to a $0.8-\mathrm{ft}$ rise in Nebraska (table 2). The area-weighted, average water-level change from 2009-11 for the aquifer was a $0.1-\mathrm{ft}$ decline (table 2).

The decision to set to zero the water-level change values in the raster cells representing the area of no substantial change (changes ranging from a $1-\mathrm{ft}$ decline to a $1-\mathrm{ft}$ rise) was examined by recalculating area-weighted, average water-level change from 2009-11without altering the cell values from their topogrid-interpolated value (table 2). The resulting areaweighted, average water-level change for the aquifer was an overall decline of $0.2 \mathrm{ft}$, and changes by State ranged from a decline of $1.2 \mathrm{ft}$ in Texas to a rise of $0.9 \mathrm{ft}$ in Nebraska. These results indicate that the decision to set raster cells to zero for the areas of no substantial water-level change, 2009-11, did not substantially affect the area-weighted, average water-levelchange calculations. Assigning cell values of zero to the areas with interpolated water-level change between a 1-ft decline to a $1-\mathrm{ft}$ rise was preferred for calculating the final values reported herein, partly because water-level measurement accuracy is estimated to be from $0.01 \mathrm{ft}$ to $1 \mathrm{ft}$.

Using the Thiessen-polygon method from previous reports (McGuire, 2009, 2011), area-weighted, average waterlevel change in the High Plains aquifer during 2009-11 was $0.0 \mathrm{ft}$. Area-weighted, average water-level change by State ranged from a decline of $1.7 \mathrm{ft}$ in Texas to a rise of $1.4 \mathrm{ft}$ in Nebraska (table 2). These results using the Thiessen-polygon method from previous reports (McGuire, 2009, 2011) do not vary substantially from the results obtained using methods described herein for the States of Texas, Kansas, or for the aquifer overall, but do vary substantially for the other States. Substantial variance occurs when there are relatively large areas with few water-level measurements, such as exist in Colorado, Nebraska, New Mexico, Oklahoma, South Dakota, and Wyoming. For such areas, the Thiessen-polygon method will generate large polygons around the wells and assign uniformly the applicable water-level-change value calculated from measured water levels at each well to its area(s).

\section{Water in Storage, Predevelopment, 1980, 2000, 2009, and 2011}

The volume of water in storage in the High Plains aquifer has been estimated, using different methods, to have been about 3.25 billion acre-ft in 1980 (Gutentag and others, 1984), about 2.98 billion acre-ft in 2000 (McGuire and others, 2003), about 2.90 billion acre- $\mathrm{ft}$ in 2009 (McGuire, 2011), and recalculated, as about 2.96 billion acre-ft in 2009 (McGuire, 2012). Water in storage in the High Plains aquifer in 2011 is estimated in this report as 2.96 billion acre-ft. Water in storage, 2011, was calculated using the raster of water-level changes from 2009-11, which was generated for this report, and rasters of saturated thickness for 2009 and of averagemapped specific yield (Gutentag and others, 1984; Cederstrand and Becker, 1998; McGuire and others, 2012). Water in storage, predevelopment, was calculated as 3.20 billion acre- $\mathrm{ft}$ using the rasters of water-level change, 2009-11, and waterlevel change, predevelopment to 2011, which were generated for this report, and rasters of saturated thickness, 2009, and of average-mapped specific yield (Gutentag and others, 1984; Cederstrand and Becker, 1998; McGuire and others, 2012). 
Previously reported values for water in storage in 2000 (McGuire and others, 2003) were calculated using areal average values associated with mapped polygons of the aquifer's saturated thickness and the area-weighted, average specific yield of the aquifer (15.1 percent). Previously reported values for water in storage in 2009 (McGuire, 2011) were calculated using areal average values associated with mapped polygons of saturated thickness in 2000, Thiessen polygons (Thiessen, 1911) of annual water-level changes from 2000 to 2009 , and the area-weighted, average specific yield of the aquifer (15.1 percent). Water in storage, 2009, was recalculated (McGuire and others, 2012) using a raster of saturated thickness for 2009 and a raster of average-mapped specific yield (Gutentag and others, 1984; Cederstrand and Becker, 1998).

Advantages of the method used in this report to calculate water in storage, 2011, were that this report's calculation for water in storage, 2011, uses the average-mapped specific yield raster and the interpolated values for the applicable rasters (saturated thickness and water-level change), instead of the average of the polygon ranges for associated cells. The use of average-mapped specific yield is preferred for calculating water in storage in this report because the average-mapped value better reflects the variability of aquifer characteristics than the aquifer average. The interpolated values for the applicable rasters (saturated thickness and water-level change) are preferred to an assigned average value because the interpolated value generally should be a more realistic reflection of the spatial variability in values than the polygon average.

\section{Change in Water in Storage, Predevelopment to 2011 and 2009-11}

Change in water in storage, predevelopment to 2011, which was calculated using average-mapped specific yield, was a decline of 246 Macre-ft for the aquifer overall or about an 8 percent decline in storage since predevelopment (Gutentag and others, 1984; Cederstrand and Becker, 1998; McGuire and others, 2012). Changes in storage, predevelopment to 2011 , by State, ranged from a decline of about 150 Macre-ft in Texas to a rise of 1.2 Macre-ft in Nebraska. Change in water in storage, 2009-11, was a decline of 2.8 Macre-ft overall; changes in storage from 2009-11 by State ranged from a decline of 4.5 Macre- $\mathrm{ft}$ in Texas to a rise of 4.7 Macre- $\mathrm{ft}$ in Nebraska (table 3).

Table 3. Change in water in storage in the High Plains aquifer, predevelopment to 2011 and 2009-11, by State and as an overall total, and by comparable methods from this report and previous reports.

[Positive values for increases in water in storage; negative values for decreases in water in storage; accumulated totals by State may differ from aquifer totals because of rounding]

\begin{tabular}{|c|c|c|c|c|c|c|}
\hline \multirow{3}{*}{ State } & \multicolumn{6}{|c|}{ Change in water in storage, in million acre-feet } \\
\hline & \multicolumn{2}{|c|}{$\begin{array}{l}\text { Final values calculated for this } \\
\text { report, with average-mapped specific } \\
\text { yield (range of } 2.5 \text { to } 27.5 \text { percent) }\end{array}$} & \multicolumn{2}{|c|}{$\begin{array}{l}\text { Calculated for this report, with } \\
\text { area-weighted, average specific } \\
\text { yield of the aquifer (15.1 percent) }\end{array}$} & \multicolumn{2}{|c|}{$\begin{array}{l}\text { Calculated using methods } \\
\text { from previous reports }\end{array}$} \\
\hline & $\begin{array}{c}\text { Predevelopment } \\
\text { to } 2011\end{array}$ & 2009-11 & $\begin{array}{c}\text { Predevelopment } \\
\text { to } 2011\end{array}$ & 2009-11 & $\begin{array}{c}\text { Predevelopment } \\
\text { to } 2011\end{array}$ & 2009-11 \\
\hline Colorado & -16.9 & 0.4 & -14.8 & 0.3 & -18.7 & 0.7 \\
\hline Kansas & -62.4 & -2.8 & -58.2 & -2.7 & -67.9 & -3.2 \\
\hline Nebraska & 1.2 & 4.7 & 1.1 & 4.8 & -8.1 & 8.5 \\
\hline New Mexico & -8.7 & -0.1 & -8.2 & -0.1 & -11.8 & -0.4 \\
\hline Oklahoma & -9.4 & -0.5 & -7.5 & -0.4 & -13.8 & -0.8 \\
\hline South Dakota & 0.1 & 0.1 & 0.2 & 0.1 & -0.3 & 0.2 \\
\hline Texas & -149.7 & -4.5 & -136.5 & -4.1 & -150.3 & -5.8 \\
\hline Wyoming & -0.4 & 0.0 & -0.7 & 0.1 & -1.7 & 0.9 \\
\hline High Plains aquifer & -246.2 & -2.8 & -224.6 & -1.9 & -272.6 & 0.1 \\
\hline
\end{tabular}


Changes in water in storage, predevelopment to 2011 and 2009-11, were recalculated a second time using the same data and methods as were used in this report's final calculations, except for using area-weighted, average specific yield of the aquifer (15.1 percent) instead of average-mapped specific yield (Gutentag and others, 1984). The change in water in storage results for the aquifer from the second calculation were a decline of about 225 Macre-ft, predevelopment to 2011, and a decline of 1.9 Macre-ft, 2009-11 (table 3). The differences in the change-in-water-in-storage value for the aquifer using area-weighted, average specific yield of the aquifer instead of average-mapped specific yield are 21.6 Macre-ft less decline from predevelopment to 2011 and 0.9 Macre-ft less decline from 2009-11. The use of average-mapped specific yield instead of area-weighted, average specific yield of the aquifer is preferred for the purposes of this report because averagemapped specific yield better reflects the variability of aquifer characteristics.

Changes in water in storage, predevelopment to 2011 and 2009-11, were recalculated a third time using methods from previous reports (McGuire, 2009, 2011). Change in water in storage, predevelopment to 2011, using methods from previous reports, was a decline of about 273 Macre-ft for the aquifer, or 26.4 Macre-ft more decline than was calculated as the final value for this report (table 3). A decrease of 2.8 Macre-ft of water in storage in the High Plains aquifer, 2009-11, was calculated using this report's methods, whereas, using methods from previous reports (Thiessen polygons), the result was a 0.1 Macre-ft increase (table 3). These methodrelated differences in results for change in water in storage from predevelopment to 2011 and from 2009-11 are caused by two methods variations: (1) use of the spatially varying raster of average-mapped specific yield (2.5 to 27.5 percent) for this report instead of the area-weighted, average specific yield for the aquifer (15.1 percent); and (2) different methods for quantifying water-level change. In the method used for previous reports (McGuire, 2009, 2011), the maps of water in storage, 2000; change in water in storage, predevelopment to 2000; and accumulated annual water-level changes since the year 2000 were used to calculate the change in water in storage from predevelopment to the applicable year. An advantage of the method used in previous reports is that wells measured for the annual water-level change comparison periods from 2000 to the report year are included in the calculation. Disadvantages of the method used in previous reports are the use of areaweighted, average specific yield and a less straight-forward method for quantifying water-level change. In the methods used for this report, the 3,322 wells measured in the predevelopment and 2011 periods and the final contours of water-level changes, predevelopment to 2011, were used as inputs. Advantages of the methods used in this report are the use of averagemapped specific yield and a more straight-forward calculation method for water-level change. If a predevelopment water level could be estimated for the 5,088 wells measured in 2011 and not measured in predevelopment (table 1), possibly the change in storage value reported herein (table 3 ) would be more similar to the value calculated in previous reports (McGuire, 2009, 2011).

\section{Percent Change in Saturated Thickness, Predevelopment to 2011}

The map of percentage change in saturated thickness (fig. 2) presents predevelopment-to-2011 water-level changes, as a percentage of predevelopment saturated thickness. This map (fig. 2) is similar in some areas to the water-level-change map (fig. 1); however, a large water-level change would not correspond to a substantial percentage change in saturated thickness if the predevelopment saturated thickness was large relative to the water-level change. Conversely, an area with small water-level change may correspond to a large percentage change in saturated thickness if its predevelopment saturated thickness was small. By 2011, 15 percent of the aquifer area had a saturated thickness decrease of more than 25 percent since predevelopment, 5 percent of the aquifer area had more than a 50-percent decrease in saturated thickness, and 1 percent of the aquifer area had more than a 10-percent increase in saturated thickness. 


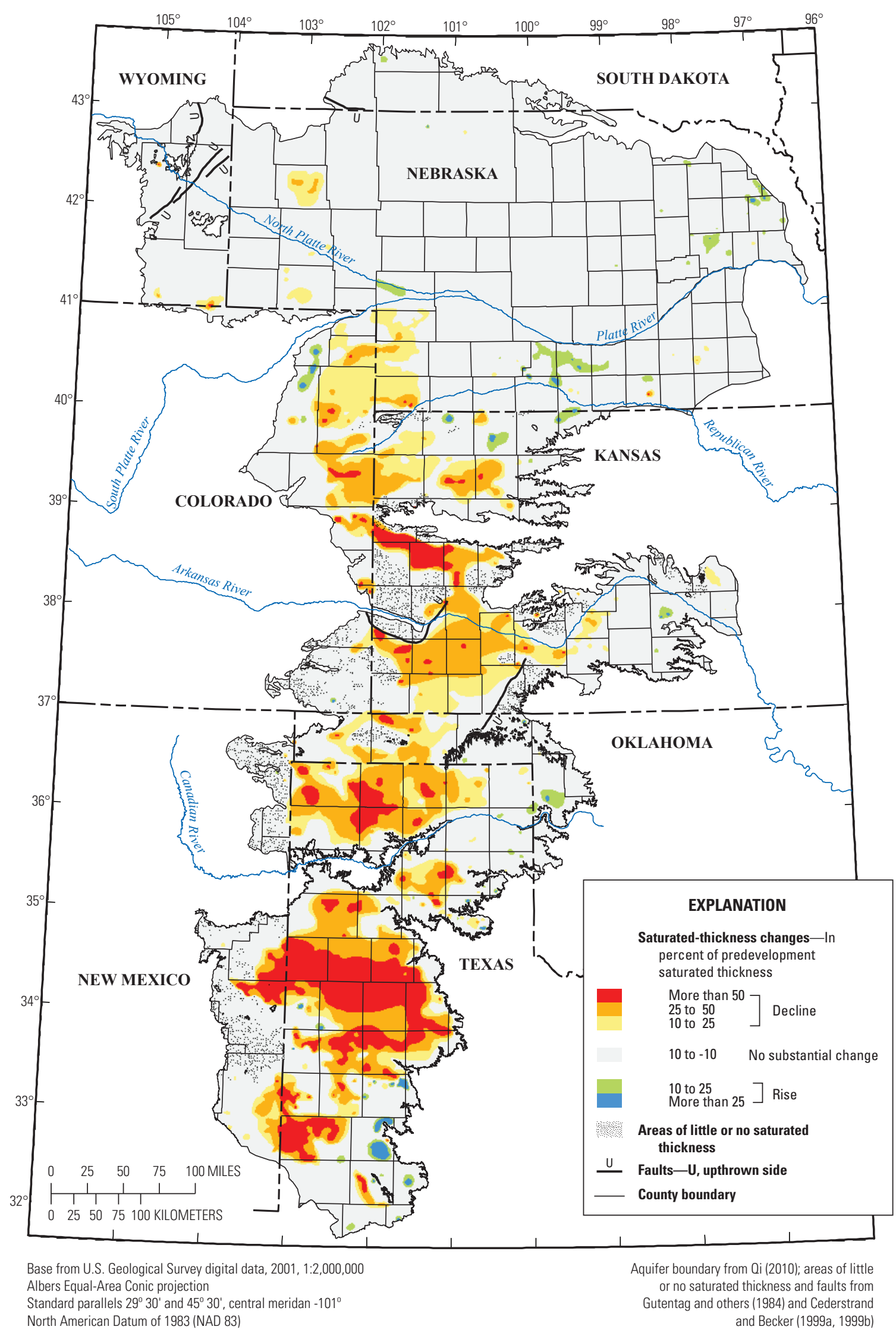

Figure 2. Change in saturated thickness of the High Plains aquifer, predevelopment to 2011. 


\section{Summary}

The High Plains aquifer underlies 111.8 million acres (175,000 square miles) in parts of eight States - Colorado, Kansas, Nebraska, New Mexico, Oklahoma, South Dakota, Texas, and Wyoming. Water-level declines began in parts of the High Plains aquifer soon after the onset of substantial irrigation with groundwater (about 1950). In response to water-level declines, Congress directed the U.S. Geological Survey to monitor water levels in the aquifer; in 1987-88, the U.S. Geological Survey, in collaboration with numerous Federal, State, and local water-resources entities, began monitoring water levels in more than 7,000 wells. Water levels were measured in 9,178 wells in 2009 and 8,410 wells in 2011.

This report presents water-level changes in the High Plains aquifer from predevelopment (generally before 1950) to 2011 and from 2009-11. The water levels used in this report generally were measured in winter or early spring, when irrigation wells typically were not pumping, and after water levels generally had recovered from pumping during the previous irrigation season. The report also presents total water in storage, 2011, and changes in water in storage and in saturated thickness from predevelopment to 2011. The methods to calculate area-weighted, average water-level changes; changes in water in storage; and total water in storage for this report used geospatial data layers organized as rasters with a cell size of about 62 acres. These methods were modified from methods used in previous reports in an attempt to improve estimates of water-level changes and change in water in storage.

The map of water-level changes in the High Plains aquifer from predevelopment to 2011 is based on water levels from 3,322 wells and other published data. Water-level changes from predevelopment to 2011, in individual wells, ranged from a rise of 85 feet (ft) in Nebraska to a decline of $242 \mathrm{ft}$ in Texas. The area-weighted, average water-level change from predevelopment to 2011 was an overall decline of $14.2 \mathrm{ft}$.

Water levels were measured in 7,376 wells before the irrigation season in 2009 and 2011; water-level changes in the measured wells ranged from about a $26-\mathrm{ft}$ decline in Texas to about a 16-ft rise in Colorado. The area-weighted, average water-level change in the High Plains aquifer during 2009-11 was a decline of $0.1 \mathrm{ft}$.

Total water in storage in 2011 was about 2.96 billion acre-feet overall, which was a decline of about 246 million acre-feet (or about 8 percent) since predevelopment. By 2011, 15 percent of the aquifer area had a saturated thickness decrease of more than 25 percent from its predevelopment saturated thickness, 5 percent of the aquifer area had more than a 50-percent decrease, and 1 percent of the aquifer area had more than a 10-percent increase.

\section{References Cited}

Alley, W.M., Reilly, T.E., and Franke, O.L., 1999, Sustainability of ground-water resources: U.S. Geological Survey Circular 1186, 79 p. (Also available at http://pubs.usgs.gov/ circ/circ1186/.)

Cederstrand, J.R., and Becker, M.F., 1998, Digital map of specific yield for High Plains aquifer in parts of Colorado, Kansas, Nebraska, New Mexico, Oklahoma, South Dakota, Texas, and Wyoming: U.S. Geological Survey Open-File Report 98-414: Accessed August 2011, at http://water.usgs. gov/GIS/metadata/usgswrd/XML/ofr98-414.xml.

Cederstrand, J.R., and Becker, M.F., 1999a, Digital map of geologic faults for the High Plains Aquifer in parts of Colorado, Kansas, Nebraska, New Mexico, Oklahoma, South Dakota, Texas, and Wyoming: U.S. Geological Survey Open-File Report 99-261: Accessed August 2011, at http:// water.usgs.gov/GIS/metadata/usgswrd/XML/ofr99-261.xml.

Cederstrand, J.R., and Becker, M.F., 1999b, Digital map of areas of little or no saturated thickness for the High Plains Aquifer in parts of Colorado, Kansas, Nebraska, New Mexico, Oklahoma, South Dakota, Texas, and Wyoming: U.S. Geological Survey Open-File Report 99-266: Accessed August 2011, at http://water.usgs.gov/GIS/metadata/ usgswrd/XML/ofr99-266.xml.

Cunningham, W.L., and Schalk, C.W., comps., 2011, Groundwater technical procedures of the U.S. Geological Survey: U.S. Geological Survey Techniques and Methods, book 1, chap. A1, 151 p. (Available only at http://pubs.usgs.gov/ $\mathrm{tm} / \mathrm{lal} /$.)

Environmental Systems Research Institute, 1992, Understanding GIS - The Arc/Info method: Redlands, Calif., Environmental Systems Research Institute, 450 p.

Environmental Systems Research Institute, 2010, ArcDoc version 9.3: Redlands, Calif., Environmental Systems Research Institute software documentation [on-line documentation and instructions included with software].

Gutentag, E.D., Heimes, F.J., Krothe, N.C., Luckey, R.R., and Weeks, J.B., 1984, Geohydrology of the High Plains aquifer in parts of Colorado, Kansas, Nebraska, New Mexico, Oklahoma, South Dakota, Texas, and Wyoming: U.S. Geological Survey Professional Paper 1400-B, 63 p. (Also available at http://pubs.usgs.gov/pp/1400b/report.pdf.)

Heimes, F.J., and Luckey, R.R., 1982, Method for estimating irrigation requirements from ground water in the High Plains in parts of Colorado, Kansas, Nebraska, New Mexico, Oklahoma, South Dakota, Texas, and Wyoming: U.S. Geological Survey Water-Resources Investigations Report 82-40, 64 p. 
Kansas Geological Survey, 2012, Wizard water well levels database: Lawrence, Kansas Geological Survey digital data: Accessed February 2012, at http://www.kgs.ku.edu/ Magellan/WaterLevels/index.html.

Kenny, J.F., Barber, N.L., Hutson, S.S., Linsey, K.S., Lovelace, J.K., and Maupin, M.A., 2009, Estimated use of water in the United States in 2005: U.S. Geological Survey Circular 1344, 52 p. (Also available at http://pubs.usgs.gov/ circ/1344/.)

Lowry, M.E., Crist, M.A., and Tilstra, J.R., 1967, Geology and ground-water resources of Laramie County, Wyoming, with a section on Chemical quality of ground water and of surface water, by J.R. Tilstra: U.S. Geological Survey Water-Supply Paper 1834, 71 p. (Also available at http:// pubs.er.usgs.gov/publication/wsp1834.)

Luckey, R.R., and Becker, M.F., 1999, Hydrogeology, water use, and simulation of flow in the High Plains aquifer in northwestern Oklahoma, southeastern Colorado, southwestern Kansas, northeastern New Mexico, and northwestern Texas: U.S. Geological Survey Water-Resources Investigations Report 99-4104, 68 p. (Also available at http://pubs. usgs.gov/wri/wri994104/.)

Luckey, R.R., Gutentag, E.D., and Weeks, J.B., 1981, Waterlevel and saturated-thickness changes, predevelopment to 1980, in the High Plains aquifer in parts of Colorado, Kansas, Nebraska, New Mexico, Oklahoma, South Dakota, Texas, and Wyoming: U.S. Geological Survey Hydrologic Investigations Atlas HA-652, 2 sheets, scale 1:2,500,000. (Also available at http://pubs.er.usgs.gov/publication/ ha652.)

Maupin, M.A., and Barber, N.L., 2005, Estimated withdrawals from principal aquifers in the United States, 2000: U.S. Geological Survey Circular 1279, 46 p. (Also available at http://pubs.usgs.gov/circ/2005/1279/.)

McGuire, V.L., 2003, Water-level changes in the High Plains aquifer, predevelopment to 2001, 1999 to 2000, and 2000 to 2001: U.S. Geological Survey Fact Sheet 078-03, 4 p. (Also available at http://pubs.usgs.gov/fs/FS078-03/.)

McGuire, V.L., 2004a, Water-level changes in the High Plains aquifer, predevelopment to 2002, 1980 to 2002, and 2001 to 2002: U.S. Geological Survey Fact Sheet 2004-3026, 6 p. (Also available at http://pubs.usgs.gov/fs/2004/3026/.)

McGuire, V.L., 2004b, Water-level changes in the High Plains aquifer, predevelopment to 2003 and 2002 to 2003: U.S. Geological Survey Fact Sheet 2004-3097, 6 p. (Also available at http://pubs.usgs.gov/fs/2004/3097/.)
McGuire, V.L., 2007, Water-level changes in the High Plains aquifer, predevelopment to 2005 and 2003 to 2005 : U.S. Geological Survey Scientific Investigations Report 2006-5324, 7 p. (Also available at http://pubs.usgs.gov/ sir/2006/5324/.)

McGuire, V.L., 2009, Water-level changes in the High Plains aquifer, predevelopment to 2007, 2005-06, and 2006-07: U.S. Geological Survey Scientific Investigations Report 2009-5019, 9 p. (Also available at http://pubs.usgs.gov/ sir/2009/5019/.)

McGuire, V.L., 2011, Water-level changes in the High Plains aquifer, predevelopment to 2009, 2007-08, and 2008-09, and change in water in storage, predevelopment to 2009: U.S. Geological Survey Scientific Investigations Report 2011-5089, 13 p. (Also available at http://pubs.usgs.gov/ sir/2011/5089/.)

McGuire, V.L., Johnson, M.R., Schieffer, R.L., Stanton, J.S., Sebree, S.K., and Verstraeten, I.M., 2003, Water in storage and approaches to ground-water management, High Plains aquifer, 2000: U.S. Geological Survey Circular 1243, 51 p. (Also available at http://pubs.usgs.gov/circ/2003/circ1243/.)

McGuire, V.L., Lund, K.D., and Densmore, B.K., 2012, Saturated thickness and water in storage in the High Plains aquifer, 2009, and water-level changes and changes in water in storage in the High Plains aquifer, 1980 to 1995, 1995 to 2000, 2000 to 2005, and 2005 to 2009: U.S. Geological Survey Scientific Investigations Report 2012-5177, 28 p. (Also available at http://pubs.usgs.gov/sir/2012/5177/.)

Meinzer, O.E., 1923, Outline of ground-water hydrology, with definitions: U.S. Geological Survey Water-Supply Paper 494, 71 p. (Also available at http://pubs.usgs.gov/wsp/0494/ report.pdf.)

Qi, S.L., 2010, Digital map of aquifer boundary for the High Plains aquifer in parts of Colorado, Kansas, Nebraska, New Mexico, Oklahoma, South Dakota, Texas, and Wyoming: U.S. Geological Survey Data Series 543. (Also available at http://pubs.usgs.gov/ds/543/.)

Taylor, C.J., and Alley, W.M., 2001, Ground-water-level monitoring and the importance of long-term water-level data: U.S. Geological Survey Circular 1217, 68 p. (Also available at http://pubs.usgs.gov/circ/circ1217/.)

Texas Water Development Board, 2012, Groundwater database: Austin, Texas Water Development Board digital data: Accessed March 2012, at http://www.twdb.state.tx.us/ groundwater/data/gwdbrpt.asp. 
Thelin, G.P., and Heimes, F.J., 1987, Mapping irrigated cropland from Landsat data for determination of water use from the High Plains aquifer in parts of Colorado, Kansas, Nebraska, New Mexico, Oklahoma, South Dakota, Texas, and Wyoming: U.S. Geological Survey Professional Paper 1400-C, 38 p. (Also available at http://pubs.usgs.gov/ pp/1400c/report.pdf.)

Thiessen, A.H., 1911, Precipitation averages for large areas: Monthly Weather Review, v. 39, p. 1,082-1,084.

Tomlin, C.D., and Berry, J.K., 1979, A mathematical structure for cartographic modeling in environmental analysis, in American Congress on Surveying and Mapping, 39th, Washington, D.C., 1979, Proceedings: Falls Church, Va., American Congress on Surveying and Mapping, p. 269283.

U.S. Department of Agriculture, 1999, 1997, Census of agriculture, volume 1, geographic area series, part 51: National Agricultural Statistics Service, AC97-CD-VOL1-1B, CDROM.

U.S. Department of Agriculture, 2004, 2002 Census of agriculture, volume 1, chapter 2, County level data: National Agriculture Statistics Service: Accessed July 2006, at http:// www.agcensus.usda.gov/Publications/2002/index.asp.

U.S. Geological Survey, 2008, Water use in the United States: U.S. Geological Survey digital data [groundwater-use data by county for 1985, 1990, 1995, 2000 and 2005]: Accessed December 2008, at http://water.usgs.gov/watuse/.

U.S. Geological Survey, 2012a, U.S. Geological Survey Groundwater Information Systems for Colorado, Kansas, Nebraska, New Mexico, Oklahoma, South Dakota, Texas, and Wyoming: U.S. Geological Survey digital data: Accessed on U.S. Geological Survey intenal network from January to March, 2012.

U.S. Geological Survey, 2012b, National Water Information System: U.S. Geological Survey digital data: Accessed January to August, 2012, at http://waterdata.usgs.gov/nwis/ gw.

U.S. Public Law 98-242, Water Resources Research Act of 1984-March 22, 1984: Accessed December 2012, at http:// thomas.loc.gov/cgi-bin/bdquery/z?d098:SN00684:|TOM:/ bss/d098query.html.

U.S. Public Law 99-662, Water Resources Development Act of 1986-November 17, 1986: Accessed December 2012, at http://thomas.loc.gov/cgi-bin/bdquery/z?d099:H.R.6:
University of Nebraska-Lincoln, Conservation and Survey Division, 2012, Groundwater-level changes in Nebraska from predevelopment to spring 2011: Lincoln, University of Nebraska-Lincoln, Conservation and Survey Division, digital map graphic: Accessed July 2012, at http://snr.unl. edu/data/water/groundwatermaps.asp.

Weeks, J.B., and Gutentag, E.D., 1981, Bedrock geology, altitude of base, and 1980 saturated thickness of the High Plains aquifer in parts of Colorado, Kansas, Nebraska, New Mexico, Oklahoma, South Dakota, Texas, and Wyoming: U.S. Geological Survey Hydrologic Investigations Atlas HA-648, 2 sheets, scale 1:2,500,000. (Also available at http://pubs.er.usgs.gov/publication/ha648.) 
Publishing support provided by: Rolla Publishing Service Center

For more information concerning this publication, contact: Director, USGS Nebraska Water Science Center 5231 South 19th Street Lincoln, Nebraska 68512 (402) 328-4100

Or visit the Nebraska Water Science Center Web site at: http://ne.water.usgs.gov/ 



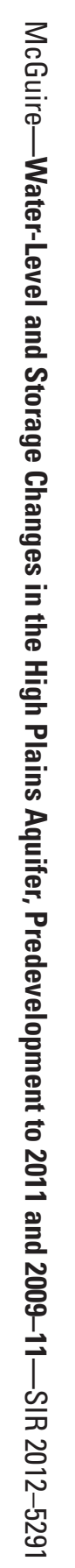

